\section{On-farm Evaluations of Wood-derived, Waste Paper, and Plastic Mulch Materials for Weed Control in Florida Container Nurseries}

\author{
S. Christopher Marble ${ }^{1}$, Shawn T. Steed ${ }^{2}$, Debalina Saha ${ }^{3}$, \\ and Yuvraj Khamare ${ }^{1}$
}

ADDITIONAL INDEX WORDs. hardwood, herbicide, pine bark, sawdust, tackifier

SuMmary. Mulches have been evaluated extensively as a weed management tool in container plant production, but most research has focused on loose-fill wood-derived mulch materials, such as pine bark or wood chips. In this experiment, pine (mixed Pinus sp.) bark (PB), shredded hardwood (HW), and pine sawdust were evaluated for weed control and crop response both alone and in combination with a guar gum tackifier alongside a plastic film mulch, a paper slurry mulch, and the paper slurry mulch $+\mathrm{PB}$ and compared with a nonmulched, nontreated control and a single application of preemergence herbicide (oxyfluorfen + pendimethalin).

Mulch materials were applied to nursery containers ranging from 7 to 25 gal at two different nurseries and at two research centers in central Florida in 2017 and 2018. Results showed that the plastic mulch provided more than a $90 \%$ reduction in hand weeding time and weed weight over a 6-month period, and similar control was achieved with $P B$, paper slurry $+P B$, and the $H W$ treatment (64\% to $91 \%$ reduction in weeding time and weed weight). No growth differences were observed with any mulch treatment in any species evaluated including ligustrum (Ligustrum japonicum), Chinese elm (Ulmus parvifolia), or podocarpus (Podocarpus macrophyllum).

$\mathrm{W}$ Teed management in container plant production is challenging, primarily due to limited postemergence herbicide options and the consequential need for supplemental hand weeding (Case et al., 2005). Currently, weed control in container nurseries is primarily achieved using preemergence herbicides. Although effective, crop

Received for publication 17 June 2019. Accepted for publication 1 Aug. 2019.

Published online 8 October 2019.

${ }^{1}$ Environmental Horticulture Department, Mid-Florida Research and Education Center, Institute of Food and Agricultural Sciences, University of Florida, 2725 S. Binion Road, Apopka, FL 32703

${ }^{2}$ University of Florida, Institute of Food and Agricultural Sciences Extension, 5339 County Road 579, Seffner, FL 33584

${ }^{3}$ Department of Horticulture, Michigan State University, 1066 Bogue Street, East Lansing, MI 48824

Funding for this research was provided by the U.S. Department of Agriculture Southern Sustainable Agriculture Research and Education on-farm grant program. S.C.M. is an Assistant Professor.

S.T.S. is a Multi-county Environmental Horticulture Production Agent III.

D.S. is a Former Graduate Research Assistant.

Y.K. is a Graduate Research Assistant.

S.C.M. is the corresponding author. E-mail: marblesc@ufl.edu.

This is an open access article distributed under the CC BY-NC-ND license (https://creativecommons.org/ licenses/by-nc-nd/4.0/).

https://doi.org/10.21273/HORTTECH04437-19 phytotoxicity can be a concern with many ornamental species that are sensitive to these herbicides. Further, limited options exist that are both safe on a wide variety of ornamentals and that also provide broad-spectrum weed control (Neal et al., 2017). Nontarget loss is also a concern in many instances, both in terms of cost and in terms of environmental stewardship. In smaller containers (e.g., 1 gal) spaced can tight (container to container with no spacing), losses can exceed $20 \%$. At a pot spacing of 8 inches, $51 \%$ of the applied granular herbicide falls in-between containers, unavailable for weed control. At 12-inch spacing, up to $80 \%$ nontarget loss can be observed (Gilliam et al., 1992). Herbicides deposited in-between containers can increase the amount of herbicide detected in captured or reused irrigation water in containment ponds, and could lead to problems with phytotoxicity in some instances (Wilson et al., 1996). These nontarget losses are especially problematic for producers of large container ornamentals ( 7 gal or larger) that may be spaced several feet apart to facilitate pruning, fertilization, weeding, and other tasks along with allowing ample space for crop growth.

Many mulch products have been recommended as a means of addressing weed control challenges in ornamental plant production (Chalker-Scott, 2007). Richardson et al. (2008) reported over 5 months of weed control with pine bark nuggets in 3- to 7-gal nursery containers, and Cochran et al. (2009) reported that 1 inch of pine bark mulch reduced spotted spurge (Euphorbia maculata) and eclipta (Eclipta prostrata) growth by more than $80 \%$ compared with a nonmulched control. Similarly, Bartley et al. (2017) reported $90 \%$ to $100 \%$ control for more than 3 months with three different wood-derived mulches. Weed discs, plastic bags (Chong, 2003), rice (Oryza sativa) hulls (Altland et al., 2016), pelletized shredded newspaper (Smith et al., 1998), chopped paper waste (Pellett and Heleba, 1995), and many other materials have been evaluated with varying levels of success (Case et al., 2005; Mathers, 2003). Previous reviews of the literature show that mulch depth and physical characteristics, that is, their ability to block light, dry quickly, and decompose slowly, contribute more toward weed suppression than the type of mulch being used (Case et al., 2005; Chalker-Scott, 2007; Marble et al., 2015). In addition to weed control benefits, mulch also may increase growth of ornamental plants. Many studies have demonstrated that mulch aids in establishment and survival of landscape or field-grown plants (Chalker-Scott, 2007; Cregg and Schutzki, 2009; Smith et al., 2000). Fewer studies

\begin{tabular}{lllc}
\hline $\begin{array}{l}\text { Units } \\
\text { To convert U.S. to SI, } \\
\text { multiply by }\end{array}$ & U.S. unit & SI unit & $\begin{array}{l}\text { To convert SI to U.S., } \\
\text { multiply by }\end{array}$ \\
\hline 3.7854 & gal & $\mathrm{L}$ & 0.2642 \\
2.54 & inch $(\mathrm{es})$ & $\mathrm{cm}$ & 0.3937 \\
1.1209 & $\mathrm{lb} / \mathrm{acre}^{-}$ & $\mathrm{kg} \cdot \mathrm{ha}^{-1}$ & 0.8922 \\
0.5933 & $\mathrm{lb} / \mathrm{yard}^{3}$ & $\mathrm{~kg} \cdot \mathrm{m}^{-3}$ & 1.6856 \\
0.0254 & $\mathrm{mil}(\mathrm{s})$ & $\mathrm{mm}$ & 39.3701 \\
28.3495 & $\mathrm{oz}$ & $\mathrm{g}$ & 0.0353
\end{tabular}


have focused on the effects of mulch in container plant production, but depths of $\approx 2$ inches or less have been shown to either increase plant growth or have no effect (Amoroso et al., 2010; Billeaud and Zajicek, 1989).

Mulch applied at an adequate depth, typically 1 inch or greater, has been shown to provide greater weed control compared with one herbicide application, as evidenced by previous reports (Bartley et al., 2017; Marble et al., 2017; Saha et al., 2019); however, use of mulch for weed control has not been widely adopted in the nursery industry. The primary barrier to adoption is cost and ease of application. Costs will vary depending on nursery location, mulch availability, mulch type, and application efficiency, but even with a significant amount of preemergence herbicide landing off-target, one application of preemergence herbicide is considerably less expensive than a single mulch application. For a 7-gal container, a hardwood mulch may cost $\approx \$ 0.15$ per pot retail, whereas a standard preemergence herbicide would cost $\approx \$ 0.01$, not including labor. Application is also difficult and time-consuming, especially when pots are already spaced in the field and mulching is not completed at potting. In Florida, strong winds during frequent summer thunderstorms may also blow mulch out of pots or result in pot blow-over, which also dislodges or removes mulch. Lighter mulch materials, such as rice hulls, also are prone to blowing out of containers or may be removed by birds.

Two novel mulch types or application methods have been described previously that may have the ability to reduce weed control in container plant production. Cline et al. (2011) reported on the use of a spray-on mulch derived from recycled newsprint fiber. The sprayon paper mulch also was evaluated with and without use of a guar-based tackifier. Tackifiers or "soil glues" are composed of guar gum or other natural starches or synthetic materials, and are often used in erosion control hydro-mulching operations. These tackifiers have been evaluated in combination with shredded paper in container plant production (Pellett and Heleba, 1995). In studies by
Cline et al. (2011), a spray-on mulch provided greater reduction in weed counts compared with a glyphosate check on several evaluation dates over 3 years and increased apple (Malus sp.) yields. Another novel mulch in container plant production is plastic. Use of a plastic film, similar to plastic used in vegetable production, was evaluated by Steed et al. (2018). The authors reported that the plastic mulch provided a high degree of weed control in nonspaced ligustrum in 1 -gal containers, but did slow production time by 2 to 3 weeks due to reduced growth rates. Both of these methods (spray-on mulch or plastic) could potentially solve application issues in container plant production and provide growers with additional weed management tools. Similarly, use of tackifiers could potentially keep mulch more stable in containers and more resilient to wind storms or during normal nursery operations when pots are moved throughout the nursery. The objective of this trial was to evaluate the use of common mulch materials with and without the use of a tackifier to alternative mulch materials including a paper slurry and a plastic mulch for weed control in container nurseries in Florida.

\section{Materials and methods}

Experiments were conducted at two central Florida nurseries in 2017 (Dover and Ruskin, FL), at a central Florida nursery (Dover), and at University of Florida Research and Education Centers in Apopka and Balm in 2018. Experiments were initiated at both nurseries on 25 Apr. Mulch treatments evaluated at both locations included PB mini-nuggets (Old Castle Lawn \& Garden, Atlanta, GA), PB + a tackifier (Granite Seed, North Lehi, UT), a shredded hardwood mulch HHW [derived from melaleuca trees (Melaleuca quinquenervia) (Forestry Resources, Fort Myers, FL)]\}, HW + tackifier, pine sawdust + tackifier, a recycled wastepaper mulch slurry $(P M), P M+P B$, and a 1.25-mil white polyethylene plastic film (Fig. 1). The tackifier was applied after mulch placement at a rate of $100 \mathrm{lb} /$ acre using a handshaker. The tackifier was applied as a dry powder. Once the tackifier was moistened with irrigation and redried, it bound mulch materials together (Fig. 2). Waste-paper mulch was based on a mulch previously described by Cline et al. (2011) but was modified based on available equipment. Waste paper was first shredded and mixed with equal parts water by volume in 5-gal buckets and allowed to sit overnight. The tackifier mentioned previously was added to this paper mixture at $30 \mathrm{~g} / \mathrm{gal}$ to achieve the desired consistency. A mixing paddle attachment was then used to mix the material into a slurry using a cordless drill. The paper slurry was then added to each pot by hand, completely covering the surface of the container. The plastic mulch was applied after plant liners had been planted by cutting the plastic into a sheet and securing it around the edge of the container using weatherproof tape. Plastic mulch was applied after pots were topdressed with fertilizer and was applied over the top of irrigation spray stakes. At all locations, the plastic mulch was applied by one person and it took $\approx 15 \mathrm{~s}$ per pot to place the plastic and secure it with tape. In all cases, mulch materials were initially applied to containers so that the container surface was completely covered. PB and HW were applied at 2-inch depth based on general recommendations for loosefill organic materials (Chalker-Scott, 2007). Sawdust was applied at a depth of 1 inch based on grower practices. Sawdust is not a commonly used mulch material in container plant production in Florida, and different depths have not been evaluated. However, several growers have implemented sawdust as a mulch at depths of $\approx 1$ inch with the goal of causing nitrogen immobilization as the sawdust degrades in the top portion of the pot where weed seeds are germinating (Foo et al., 2010). The paper slurry treatment has not been evaluated previously in container plant production, but we found through preliminary trialing that a depth of 1 inch would create the desired hard "crust" after drying, thus 1 -inch depth was used for the paper slurry treatment. In addition to mulch treatments, a herbicide treatment of oxyfluorfen + pendimethalin (OH2; Everris NA, Dublin, $\mathrm{OH}$ ) was included for comparison and applied at the manufacturer recommended rate of $2+1 \mathrm{lb} /$ acre active ingredient using a hand-shaker. A nontreated, 


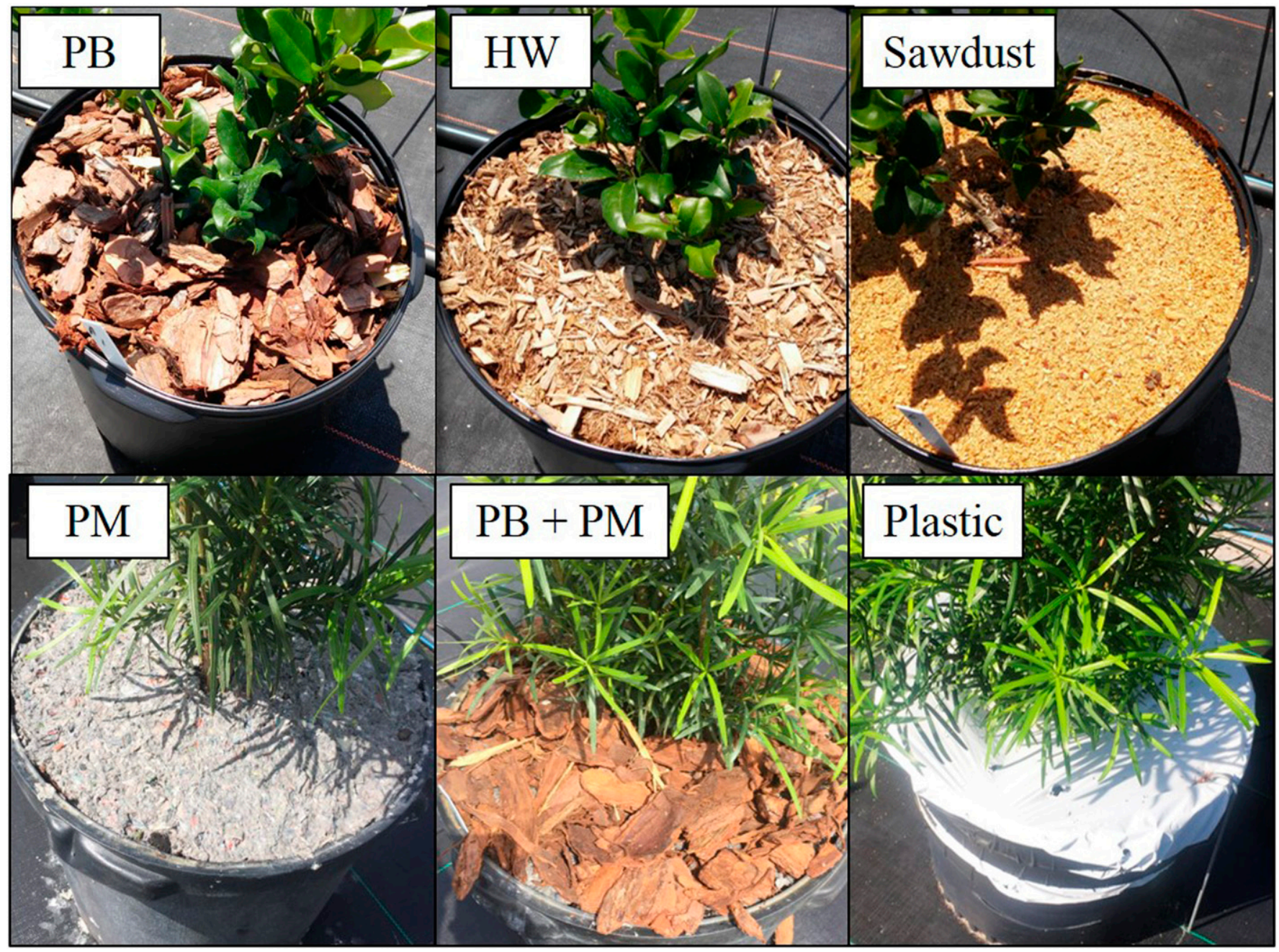

Fig. 1. Example of pine bark (PB), hardwood (HW), sawdust, paper slurry (PM), PB + PM, and plastic mulch treatments at potting. $\mathrm{PB}, \mathrm{HW}$, and sawdust treatments were also included with the addition of a guar gum tackifier (not shown).

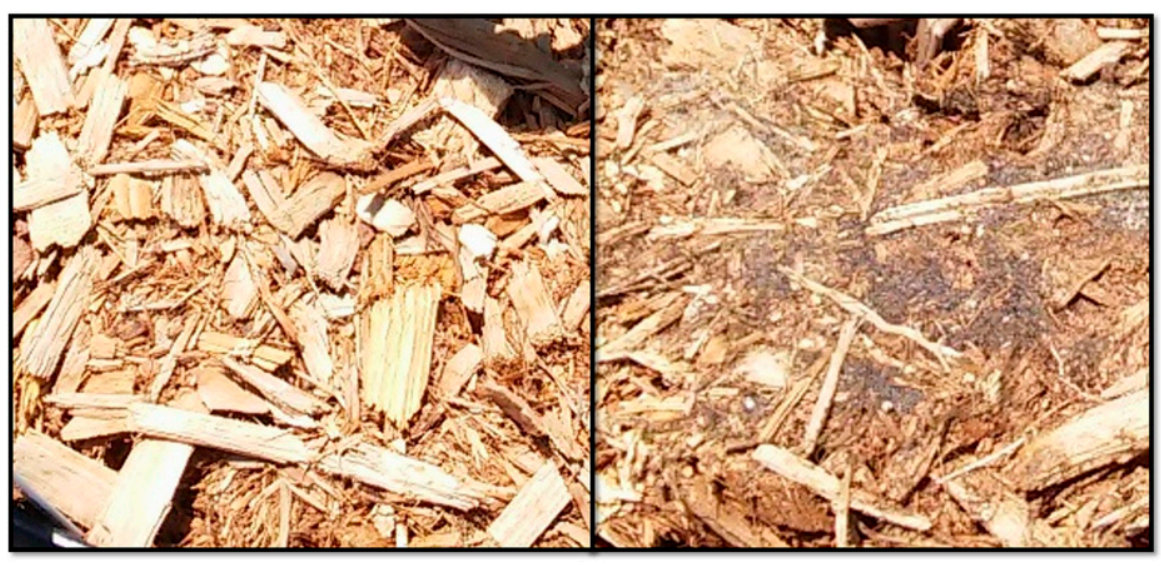

Fig. 2. Hardwood mulch alone (left) and with the addition of a guar gum tackifier (right). Photo was taken after the tackifier had been watered in and subsequently dried.

nonmulched control was also included for comparison. In Dover, treatments were applied to 15-gal podocarpus, and treatments were applied to 25-gal Chinese elms in Ruskin. At both locations, standard PB:peat substrate mixes were used and fertilizers were topdressed according to the growers' standard practices. All regular maintenance and production activities were performed by nursery cooperators except hand weeding or use of any weed control measure other than spot treatment with postemergence herbicides as needed in the adjacent production areas. The trial was designed as a completely randomized block with four single pot replications per treatment at each location. Pots were weeded by hand on a monthly basis recording the time needed to weed each pot. Weeds were then shaken to remove loose soil from roots and weighed in the field using a portable digital scale. Pots were monitored for 6 months in Dover, at which time the trial was considered concluded. In Ruskin, pots were inadvertently weeded by employees in one instance and trees were laid down to prevent wind damage from Hurricane Irma in early 
September, resulting in mulch being removed from pots. Thus, weed control data collection was not analyzed from this location. In Ruskin, tree caliper and height were recorded at trial initiation and in October after the trial concluded, and initial and final growth index [ (plant height + plant width at widest point + plant width perpendicular to widest point)/3] was recorded on podocarpus in Dover.

In 2018, the experiment was repeated at the nursery in Dover and at University of Florida research centers in Apopka and Balm. The trials were initiated on 19 Apr. in Dover and Balm and 26 Apr. in Apopka using the same mulch materials and methods described previously. 'Brodie' eastern red cedar [Juniperus virginiana (15 gal)] were evaluated in Dover using standard grower practices described previously. At research centers in Apopka and Balm, l-gal ligustrum liners were obtained from local growers and potted into 7-gal containers. In Balm, the plants were potted using a 75:25 (v:v) PB:peat substrate and fertilized via subdressing with an $18 \mathrm{~N}-2.6 \mathrm{P}-6.6 \mathrm{~K}$ controlledrelease fertilizer with micronutrients (Nutricote; Chisso-Asahi Fertilizer Co., Tokyo, Japan) at a rate of $161 \mathrm{~g}$ per container. In Apopka, a 80:20:10 PB, peat, sand (v:v:v) substrate was used with $17 \mathrm{~N}-2.2 \mathrm{P}-9.1 \mathrm{~K}$ controlledrelease fertilizer (Osmocote Pro; ICL Specialty Fertilizers, Dublin, $\mathrm{OH})$ applied via incorporation at a rate of $12 \mathrm{lb} / \mathrm{yard}^{3}$. Pots were irrigated daily using spray stakes at all locations.

Data collection included monthly weeding times and weed fresh weights at all locations for 6 months after treatments (MAT) were originally applied. Plant growth indices were collected on a subset of plants at trial initiation and at trial conclusion on ligustrum. Ligustrum liners were uniform at the time of potting, so six plants were randomly selected in Apopka and Balm to determine average initial growth index. Growth index was then recorded on all plants at trial conclusion at 6 MAT. Growth index was not recorded on eastern red cedar, as plants were pruned during the trial.

All data were subjected to a mixed model analysis of variance (ANOVA) after ensuring the assumptions of
ANOVA were met. Weed control treatment was treated as a fixed effect and location, year, and replication (block) as random effects using JMP Pro software (version 14; SAS Institute, Cary, NC). Weeding time and weed weight data were analyzed by month and cumulatively over the entire experiment to determine which mulch material provided the most effective and consistent weed control under a variety of different environments. Ligustrum growth index was analyzed similarly. As growth evaluations for podocarpus and Chinese elm were not repeated in time or space, the data were analyzed as described previously but are only briefly discussed.

\section{Results and discussion}

At 1 MAT, PB, HW, paper slurry + $\mathrm{PB}$, and plastic resulted in less weeding time than sawdust, but few other treatment effects were noted and all treatments reduced hand weeding time relative to the nontreated control (Table 1). All treatments reduced weed weight compared with the nontreated control at 1 MAT but no other treatment differences were observed at that time (Table 2). By 2 MAT, all treatments with the exception of both sawdust treatments and the herbicide treatment reduced total weeding time compared with the nontreated control, whereas all treatments with the exception of sawdust + tackifier reduced weed weights compared with the nontreated control. At 3 MAT, all treatments required similar hand weeding times but reduced weed weight relative to the nontreated control. At 4 MAT, plastic and $\mathrm{PB}+$ tackifier were the only treatments that significantly reduced both hand weeding time and weed weight relative to the nontreated control. Weeding time in $\mathrm{PB}+$ tackifier, plastic, $\mathrm{PB}, \mathrm{HW}$, paper slurry $+\mathrm{PB}$, and sawdust treatments were similar at 5 MAT and all reduced weeding time relative to the nontreated control. These treatments also resulted in lower weed weights with the exception of sawdust. Pine bark + tackifier, paper slurry $+\mathrm{PB}$, and plastic were the only treatments to reduce both weeding time and weed weight at 6 MAT.

Across all evaluation dates and trial locations, plastic mulch resulted in the greatest cumulative reduction in weeding time $(93 \%)$, with $\mathrm{PB}$, paper slurry $+\mathrm{PB}$, and the HW treatment resulting in similar reductions (64\% to $77 \%$ reductions). Treatments including HW + tackifier, sawdust, and the herbicide resulted in no significant reduction in weeding time compared with nontreated pots. All treatments reduced cumulative weed weight relative to the nontreated control. Plastic reduced weed weights greater than any other treatment (97\%) with the exception of all $\mathrm{PB}$ treatments, HW, and the paper slurry, which were similar $(70 \%$ to $91 \%$ reductions). When considering both weeding time and weed weight, plastic resulted in the greatest overall weed control, whereas $\mathrm{PB}$, paper slurry $+\mathrm{PB}$, and HW were the only treatments similar to plastic in both regards. Plastic mulch is used extensively in vegetable and fruit production (Sander, 2019) for weed control and has shown promise in preliminary container trials. Steed et al. (2018) reported a cumulative decrease in weeding time of $86 \%$ when l-gal containers planted with ligustrum were covered in 1.25 -mil plastic compared with a nonmulched control group. Although this method added minor production costs, labor savings resulting from reduced hand weeding far exceeded the added cost of installation, removal, and disposal of plastic mulch.

It is important to note that the herbicide treatment was applied only once over the course of 6 months to determine at which point mulch becomes more effective than a commonly applied herbicide. In this study, weeding time was similar between the herbicide treatment and the nontreated by 2 MAT, but reductions in weed weight were observed up until 4 MAT. In Florida, herbicides are typically applied every 8 to 10 weeks (Stewart et al., 2017). This coincides with our data showing that a reduction in weed weight was observed until 4 MAT, that is, a sequential application would have been required before $4 \mathrm{MAT}$ to achieve acceptable control. Although mulch is more difficult to apply and costlier than herbicides, it does offer advantages in terms of length of control and spectrum of control. In this trial, treatments were inoculated with naturally occurring weed populations at trial locations and thus a broad 
Table 1. Effects of mulch treatments on monthly and cumulative hand weeding times at nursery and research center locations in Florida.

\begin{tabular}{|c|c|c|c|c|c|c|c|}
\hline \multirow[b]{2}{*}{ Treatment } & \multicolumn{6}{|c|}{ Mean weeding time $(s)^{z}$} & \multirow{2}{*}{$\begin{array}{l}\text { Cumulative weeding time (s) and reduction } \\
\qquad(\%)^{\mathrm{x}}\end{array}$} \\
\hline & I MAT $^{y}$ & 2 MAT & 3 MAT & 4 MAT & 5 MAT & 6 MAT & \\
\hline Pine bark nuggets (PB) & $1.3 c^{w}$ & $2.6 \mathrm{bc}$ & $8.3 \mathrm{ab}$ & $2.3 \mathrm{bc}$ & $5.7 \mathrm{de}$ & $9.5 \mathrm{~cd}$ & $29.8(76) \mathrm{cde}$ \\
\hline Hardwood (HW) & $1.4 \mathrm{c}$ & $2.7 \mathrm{bc}$ & $18.3 \mathrm{ab}$ & $5.7 \mathrm{abc}$ & $6.3 \mathrm{de}$ & $10.1 \mathrm{~cd}$ & 44.6 (64) bcde \\
\hline $\mathrm{HW}+$ tackifier & $5.7 \mathrm{bc}$ & $3.6 \mathrm{bc}$ & $15.5 \mathrm{ab}$ & $6.4 \mathrm{abc}$ & $17.4 \mathrm{abc}$ & $29.1 \mathrm{ab}$ & $77.7(36) \mathrm{abc}$ \\
\hline Paper slurry & $5.4 \mathrm{bc}$ & $3.8 \mathrm{bc}$ & $20.6 \mathrm{ab}$ & $5.8 \mathrm{abc}$ & $16.3 \mathrm{bcd}$ & $12.4 \mathrm{~cd}$ & $64.4(47)$ bcd \\
\hline Sawdust + tackifier & $5.6 \mathrm{bc}$ & $6.5 \mathrm{ab}$ & $17.3 \mathrm{ab}$ & $5.0 \mathrm{abc}$ & $22.8 \mathrm{ab}$ & $14.2 \mathrm{~cd}$ & $71.5(42) \mathrm{bcd}$ \\
\hline Herbicide $^{v}$ & $3.7 \mathrm{bc}$ & $6.1 \mathrm{ab}$ & $14.1 \mathrm{ab}$ & $8.2 \mathrm{abc}$ & $23.6 \mathrm{ab}$ & $34.4 \mathrm{a}$ & $90.0(26) \mathrm{ab}$ \\
\hline Plastic mulch & $1.7 \mathrm{c}$ & $0.1 \mathrm{c}$ & $1.3 \mathrm{~b}$ & $0.1 \mathrm{c}$ & $3.8 \mathrm{e}$ & $1.7 \mathrm{~d}$ & $8.5(93) \mathrm{e}$ \\
\hline Nontreated control & $13.9 \mathrm{a}$ & $10.3 \mathrm{a}$ & $32.7 \mathrm{ab}$ & $16.9 \mathrm{ab}$ & $27.8 \mathrm{a}$ & $22.2 \mathrm{abc}$ & $122.3(\mathrm{NA}) \mathrm{a}$ \\
\hline
\end{tabular}

${ }^{\mathrm{z}}$ Results were pooled over three locations (Apopka, Balm, and Dover, FL) and 2 years (2017 and 2018) and shows mean weeding time per pot.

${ }^{y}$ MAT $=$ months after treatment. Treatments were applied in April in both years at all locations.

${ }^{x}$ Cumulative weeding time was calculated by summing weeding times throughout the trial in each treatment. Reduction was calculated by subjecting cumulative time to the formula [(cumulative time of nontreated - cumulative time treated)/cumulative time nontreated] $\times 100$ to show the percent reduction in time each mulch treatment provided over a nontreated control group and is shown parenthetically. Mean separation was performed on cumulative weeding time. NA $=$ not applicable.

${ }^{w}$ Means within a column followed by the same letter are not significantly different based on Fisher's least significant difference $(P<0.05)$.

${ }^{v}$ Oxyfluorfen + pendimethalin $(\mathrm{OH} 2$; Everris NA, Dublin, $\mathrm{OH})$ applied at $2+1 \mathrm{lb} / \mathrm{acre}$ a.i.; $1 \mathrm{lb} / \mathrm{acre}=1.1209 \mathrm{~kg} \cdot \mathrm{ha}{ }^{-1}$.

Table 2. Effects of mulch treatments on monthly and cumulative weed weight at nursery and research center locations in Florida.

\begin{tabular}{|c|c|c|c|c|c|c|c|}
\hline \multirow[b]{2}{*}{ Treatment } & \multicolumn{6}{|c|}{ Mean weed wt $(\mathrm{g})^{\mathrm{z}}$} & \multirow[b]{2}{*}{ Cumulative weed wt (g) and reduction (\%) } \\
\hline & I MAT $^{\mathrm{y}}$ & 2 MAT & 3 MAT & 4 MAT & 5 MAT & 6 MAT & \\
\hline Pine bark nuggets $(\mathrm{PB})$ & $0.3 b^{w}$ & $7.7 \mathrm{~cd}$ & $16.7 \mathrm{~b}$ & $16.1 \mathrm{bc}$ & 27.7 bcd & $44.8 \mathrm{abc}$ & $113.2(80) \mathrm{cde}$ \\
\hline Hardwood (HW) & $7.0 \mathrm{~b}$ & $8.9 \mathrm{~cd}$ & $58.6 \mathrm{~b}$ & $17.1 \mathrm{abc}$ & $18.0 \mathrm{bcd}$ & $26.5 \mathrm{c}$ & $136.1(76) \mathrm{cde}$ \\
\hline HW + tackifier & $1.7 \mathrm{~b}$ & $46.4 \mathrm{bc}$ & $74.7 \mathrm{~b}$ & $25.3 \mathrm{abc}$ & $49.7 \mathrm{abcd}$ & $94.9 \mathrm{a}$ & $292.6(49) \mathrm{bc}$ \\
\hline Paper slurry & $3.7 \mathrm{~b}$ & $6.7 \mathrm{~cd}$ & $69.9 \mathrm{~b}$ & $16.0 \mathrm{bc}$ & $41.8 \mathrm{abcd}$ & $32.7 \mathrm{bc}$ & $171.0(70)$ bcde \\
\hline Sawdust + tackifier & $1.0 \mathrm{~b}$ & $101.7 \mathrm{a}$ & $93.4 \mathrm{~b}$ & $16.7 \mathrm{abc}$ & $69.7 \mathrm{ab}$ & $51.3 \mathrm{abc}$ & $333.7(42) b$ \\
\hline Herbicide $^{\mathrm{v}}$ & $3.4 \mathrm{~b}$ & $10.8 \mathrm{~cd}$ & $60.2 \mathrm{~b}$ & $41.3 \mathrm{ab}$ & $58.8 \mathrm{abc}$ & $38.1 \mathrm{abc}$ & $212.6(63) \mathrm{bcd}$ \\
\hline Plastic mulch & $0.3 \mathrm{~b}$ & $1.2 \mathrm{~d}$ & $0.4 \mathrm{~b}$ & $0.1 \mathrm{c}$ & $6.3 \mathrm{~cd}$ & $3.3 \mathrm{c}$ & $11.5(98) \mathrm{e}$ \\
\hline Nontreated control & $16.7 \mathrm{a}$ & $86.9 \mathrm{ab}$ & $246.4 \mathrm{a}$ & $49.6 \mathrm{a}$ & $91.2 \mathrm{a}$ & $83.6 \mathrm{ab}$ & $574.5(\mathrm{NA}) \mathrm{a}$ \\
\hline
\end{tabular}

${ }^{\mathrm{z}}$ Results were pooled over three locations (Apopka, Balm, and Dover, FL) and 2 years (2017 and 2018) and shows mean weed weight per pot; $1 \mathrm{~g}=0.0353 \mathrm{oz}$.

${ }^{\mathrm{y}} \mathrm{MAT}=$ months after treating. Treatments were applied in April in both years at all locations.

${ }^{x}$ Cumulative weed weight was calculated by summing weed weights throughout the trial in each treatment. Reduction was calculated by subjecting cumulative weed weight to the formula [(cumulative weight of nontreated - cumulative weight treated)/cumulative weight nontreated] $\times 100$ to show the percent reduction in weight each mulch treatment provided over a nontreated control group and is shown parenthetically. Mean separation was performed on cumulative weed weight. NA = not applicable.

${ }^{w}$ Means within a column followed by the same letter are not significantly different based on Fisher's least significant difference $(P<0.05)$.

${ }^{v}$ Oxyfluorfen + pendimethalin $(\mathrm{OH} 2$; Everris NA., Dublin, $\mathrm{OH})$ applied at $2+1 \mathrm{lb} /$ acre a.i.; $1 \mathrm{lb} / \mathrm{acre}=1.1209 \mathrm{~kg} \cdot \mathrm{ha}^{-1}$.

spectrum of weeds was present. Oxyfluorfen + pendimethalin is a highly efficacious combination on many container weed species (Neal et al., 2017), but mulch will likely control an even broader spectrum of weed species due to its ability to create unfavorable environments for germination and growth (Saha et al., 2019).

The use of tackifier with PB, HW, or sawdust had little effect on weeding time or weed weight on most evaluation dates (Tables 1 and 2 ), similar to reports observed by Cline et al. (2011) in apple orchards. $\mathrm{PB}$ weeding time and weed weight were similar with and without tackifier on all evaluation dates and when considering cumulative weeding time or weight. Although sawdust and HW with and without tackifier were similar on most evaluation dates, in some instances greater weed growth or weed time occurred with the addition of tackifier.

Guar gum-based tackifiers as used in this experiment are commonly incorporated with organic mulch materials for use in hydroseeding and erosion management (Fehmi and Kong, 2012; Grismer and Hogan, 2005). In our study, tackifiers were evaluated primarily to determine if they could prevent mulch from blowing or washing out of the pots, which is a common concern in Florida because of frequent storm events during summer months. In our trials, little mulch was lost over the course of 6 months and the use of tackifiers provided no meaningful benefit in terms of weed control with PB, HW, or sawdust. However, tackifiers are often mixed with mulch materials before use, and tackifiers are primarily used with mulch that has been extensively processed and is of small particle size. With the exception of sawdust, the mulch evaluated here was composed of relatively large particles (Saha et al., 2019), thus tackifier 
had little influence on mulch characteristics.

Although tackifiers are typically incorporated with mulch before application, they were topdressed in these studies because of the difficulty of mixing at nursery locations, which could have reduced effectiveness. Trials also were conducted in Florida during primarily the summer months with frequent rainfall, which also likely prevented mulch blow out. Although tackifiers had little influence on results in this trial, they should be evaluated for use with other mulches, such as rice hulls, that provide a high level of weed control and dry quickly following irrigation (Altland and Krause, 2014; Altland et al., 2016) but are prone to blowing out of containers or removal by birds.

The paper slurry mulch (used alone) provided an advantage in reducing weeding time over the nontreated control on three evaluation dates ( 1,2 , and 5 MAT), a reduction in weed weight compared with the control on the first four evaluation dates. It also resulted in less cumulative weeding time and weed weight compared with the nontreated control. This paper slurry is applied wet, but soon dries to form a hard covering over the container surface. We did not notice it becoming hydrophobic at any time throughout the trials and was readily wettable with irrigation or rainfall. Higher levels of control were achieved at earlier evaluation dates, because over time, this material became prone to shrinking away from the container edge at later evaluation dates (Fig. 3). By 6 MAT, the material had begun to break down following high levels of rainfall, but still

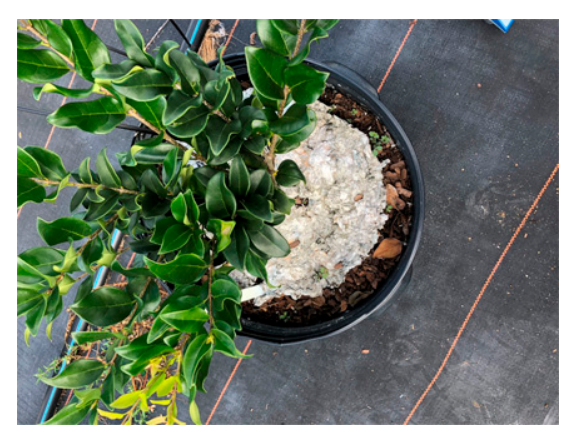

Fig. 3. Example of shrinkage observed with paper slurry mulch at later evaluation dates. Photo was taken at 3 months after trial initiation in Balm, FL. provided a cumulative advantage over the nonmulched control due to higher levels of control achieved during the first 3 months. Additional research is needed with this material and other spray-on mulches as described in Cline et al. (2011), because they could potentially be reapplied later in the production cycle. Addition of other tackifiers or polymers could also possibly extend longevity.

Growth evaluations of ligustrum at the two research locations show that plants increased in growth index by $45 \%$ to $70 \%$ over the 6 month study period and mulch type had no influence on plant growth (Table 3). Results for podocarpus in Dover and Chinese elm in Ruskin were also similar, with no difference in growth index increase in podocarpus and similar increases in tree height and caliper for elms regardless of treatment (data not shown). Although greater growth and establishment is often reported following mulch application to landscape plants (Chalker-Scott, 2007; Cregg and Schutzki, 2009), in many cases this is due to water conservation and preventing wilt after planting. In a nursery environment, water would be supplied each day and, thus, benefits to plant growth are likely to be less significant, as the nursery is an ideal growing environment.

Overall, data suggest mulch materials including $\mathrm{PB}$, and plastic mulch would provide a high level of weed control in Florida nurseries. These treatments consistently outperformed a nontreated control and a single granular herbicide application on most evaluation dates. HW mulch provided similar control to plastic and $\mathrm{PB}$ on many evaluation dates and overall in terms of reductions in weeding time and weed weight. Mulch degradation was not assessed in this study, but mulch durability will have a significant effect on weed control over time (Foo et al., 2010; Ruggeri et al., 2016). Greater durability likely contributed to higher levels of control with the larger particle materials such as PB and HW, in addition to the plastic mulch at later evaluation dates. Sawdust and paper slurry may be more effective on shorter-term crops but did not show needed durability in these 6-month evaluations.

PB has been extensively studied as a mulch, but use of plastic is relatively new. Although some growth reductions to ligustrum have been reported in previous studies with liners in 1-gal containers (Steed et al., 2018), we observed no differences in growth rates of ligustrum or any of the other species evaluated. Differences in growth are likely due to differences in irrigation practices between our study and those used in Steed et al. (2018). In our trials, we used spray stakes that were positioned underneath the plastic, whereas Steed et al. (2018) used overhead irrigation

Table 3. Effects of mulch treatments on growth index and growth increase of ligustrum in Apopka and Balm, FL.

\begin{tabular}{|c|c|c|}
\hline Treatment & Growth index (inches) $^{\mathrm{z}}$ & Increase $(\%)^{\mathrm{y}}$ \\
\hline Pine bark nuggets (PB) & $27.8^{x}$ & 62 \\
\hline $\mathrm{PB}+$ tackifier & 29.0 & 68 \\
\hline Hardwood mulch (HW) & 26.9 & 56 \\
\hline $\mathrm{HW}+$ tackifier & 27.9 & 63 \\
\hline Paper slurry & 26.9 & 56 \\
\hline Paper slurry + PB & 29.3 & 70 \\
\hline Sawdust & 27.8 & 62 \\
\hline Sawdust + tackifier & 28.2 & 63 \\
\hline Herbicide $^{\mathrm{w}}$ & 25.4 & 49 \\
\hline Plastic mulch & 27.2 & 59 \\
\hline Nontreated control & 25.0 & 45 \\
\hline \multicolumn{3}{|c|}{$\begin{array}{l}{ }^{\mathrm{z}} \text { Growth index was calculated using the formula [ }(\text { plant height }+ \text { plant width at widest point }+ \text { plant width } \\
\text { perpendicular to widest point }) / 3] \text {. Data were pooled over both locations; } 1 \mathrm{~cm}=0.3937 \text { inches. } \\
\text { y Percent increase was based on initial growth index of six replications taken on uniform liners in Apopka (mean } \\
\text { growth index of } 18.3 \mathrm{~cm}) \text { and Balm (mean growth index of } 16.1 \mathrm{~cm}) \text { at potting. Percent increase in growth is } \\
\text { shown at } 6 \text { mo. after potting with data pooled over both locations. } \\
{ }^{x} \text { Means followed by no letter are not significantly different according to Fisher's least significant difference }(P< \\
\text { O.05). } \\
\text { wOxyfluorfen + pendimethalin }(\mathrm{OH} 2 \text {; Everris NA, Dublin, OH) applied at } 2+1 \mathrm{lb} / \text { acre a.i.; } 1 \mathrm{lb} / \text { acre }=1.1209 \\
\mathrm{kg}^{\mathrm{kg}} \text { ha }^{-1} \text {. }\end{array}$} \\
\hline
\end{tabular}


on smaller ( 1 gal) containers. Steed et al. (2018) suggested that slower growth resulting from use of plastic was likely due to less available water and possibly greater accumulation of salts, as container leaching was minimal. Although leachates were not monitored in our study, placing spray stakes underneath plastic likely eliminated this potential issue, as evidenced by no differences in plant growth.

Use of plastic deserves further investigation in nursery crops because it could potentially mitigate many different production costs, including herbicides, hand weeding, fertilizer, and labor costs overall (Steed et al., 2018). Although plastic films could potentially provide advantages, there also would be disadvantages such as increasing the difficulty of monitoring irrigation (if irrigation emitters are placed under plastic) and significantly reducing the benefits of supplemental rainfall. Use of plastic sheets and tape would be cumbersome to apply on a commercial scale, but designing a plastic mulch product specifically for container nursery production, such as including drawstrings for securing the plastic on the pot, could make application more feasible. It is also important to note that use of polyethylene film is becoming more scrutinized due to negative environmental consequences resulting from plastic pollution (Brodhagen et al., 2017). When used in agricultural fields as a plastic mulch, removal is labor intensive, disposal is costly, and recycling may not be an option because soil particles can adhere tightly to the films. Another issue is that once the plastics age in the field, they are easily torn and small plastic particles contaminate soils and water bodies via runoff (Jambeck et al., 2015). Use of biodegradable plastics could be explored as a possible solution to alleviate environmental issues (Sintim and Flury, 2017), as could designing plastic mulch materials specifically for use in container nurseries to allow for reuse in multiple seasons and crops.

Costs are difficult to quantify because of many variables that affect mulch costs, but most mulches regardless of composition will be more costly than preemergence herbicide applications. However, in longerterm nursery crops in large spaced containers, the long-term control achieved with mulch and resulting reductions in hand weeding and herbicide over this longer period is likely to result in overall cost savings, as discussed in Bartley et al. (2017).

\section{Literature cited}

Altland, J. and C. Krause. 2014. Parboiled rice hull mulch in containers reduces liverwort and flexuous bittercress growth. J. Environ. Hort. 32:59-63.

Altland, J.E., J.K. Boldt, and C.C. Krause. 2016. Rice hull mulch affects germination of bittercress and creeping woodsorrel in container plant culture. Amer. J. Plant Sci. 7:2359-2375.

Amoroso, G., P. Frangi, R. Piatti, A. Fini, and F. Ferrini. 2010. Effect of mulching on plant and weed growth, substrate water content, and temperature in container-grown arborvitae. HortTechnology 20:957-962.

Bartley, P.C, III, G.R. Wehtje, A.M. Murphy, W.G. Foshee, III, and C.H. Gilliam. 2017. Mulch type and depth influences control of three major weed species in nursery container production. HortTechnology 27:465-471.

Billeaud, L.A. and J.M. Zajicek. 1989. Influence of mulches on weed control, soil $\mathrm{pH}$, soil nitrogen content, and growth of Ligustrum japonicum. J. Environ. Hort. 7:155-157.

Brodhagen, M., J.R. Goldberger, D.G. Hayes, D.A. Inglis, T.L. Marsh, and C. Miles. 2017. Policy considerations for limiting unintended residual plastic in agricultural soils. Environ. Sci. Policy 69:81-84.

Case, L.T., H.M. Mathers, and A.F. Senesac. 2005. A review of weed control practices in container nurseries. HortTechnology 15:535-545.

Chalker-Scott, L. 2007. Impact of mulches on landscape plants and the environmentA review. J. Environ. Hort. 25:239-249.

Chong, C. 2003. Experiences with weed discs and other nonchemical alternatives for container weed control. HortTechnology 13:23-27.

Cline, J., G. Neilsen, E. Hogue, S. Kuchta, and D. Neilson. 2011. Spray-on mulch technology for intensively grown irrigated apple orchards: Influence on tree establishment, early yields, and soil physical properties. HortTechnology 21:398411.

Cochran, D.R., C.H. Gilliam, D.J. Eakes, G.R. Wehtje, P.R. Knight, and J. Olive.
2009. Mulch depth affects weed seed germination. J. Environ. Hort. 2:85-90.

Cregg, B.M. and R. Schutzki. 2009. Weed control and organic mulches affect physiology and growth of landscape shrubs. HortScience 44:1419-1424.

Fehmi, J.S. and T.M. Kong. 2012. Effects of soil type, rainfall, straw mulch, and fertilizer on semi-arid vegetation establishment, growth and diversity. Ecol. Eng. 44:70-77.

Foo, C.L., K.C. Harrington, and M.B. MacKay. 2010. Comparison of weed control techniques to establish three ground cover species. N. Z. Plant Prot. 63:96-101.

Gilliam, C.H., D.C. Fare, and A. Beasley. 1992. Nontarget herbicide losses from application of granular Ronstar to container nurseries. J. Environ. Hort. 10:175-176.

Grismer, M.E. and M.P. Hogan. 2005. Simulated rainfall evaluation of revegetation/mulch erosion control in the Lake Tahoe basin-3: Soil treatment effects. Land Degrad. Dev. 16:489-501.

Jambeck, J.R., R. Geyer, C. Wilcox, T.R. Siegler, M. Perryman, A. Andrady, R. Narayan, and K.L. Law. 2015. Plastic waste inputs from land into the ocean. Science 347:768-771.

Marble, S.C., A.K. Koeser, and G. Hasing. 2015. A review of weed control practices in landscape planting beds: Part 1-Nonchemical methods. HortScience 50:851856.

Marble, S.C., A.K. Koeser, and G. Hasing. 2017. Annual cost and efficacy of common landscape weed control techniques. HortTechnology 27:199-211.

Mathers, H.M. 2003. Novel methods of weed control in containers. HortTechnology 13:28-34.

Neal, J., J.C. Chong, and J. WilliamsWoodward (eds.). 2017. Southeastern US pest control guide for nursery crops and landscape plantings. 25 May 2019. $<$ https://content.ces.ncsu.edu/ southeastern-us-pest-control-guidefornursery-crops-and-landscapeplantings $>$.

Pellett, N.E. and D.A. Heleba. 1995. Chopped newspaper for weed control in nursery crops. J. Environ. Hort. 13:7781.

Richardson, B., C.H. Gilliam, G.B. Fain, and G.R. Wehtje. 2008. Container nursery weed control with pinebark mininuggets. J. Environ. Hort. 26:144-148.

Ruggeri, R., M.E. Provenzano, and F. Rossini. 2016. Effect of mulch on initial 
coverage of four groundcover species for low input landscaping in a Mediterranean climate. Urban For. Urban Green. 19:176-183.

Saha, D., S.C. Marble, B.J. Pearson, H.E. Perez, G.E. MacDonald, and D.C. Odero. 2019. Mulch type and depth, herbicide formulation, and post-application irrigation volume influence on control of common landscape weed species. HortTechnology 29:65-77.

Sander, M. 2019. Biodegradation of polymeric mulch films in agricultural soils: Concepts, knowledge gaps, and future research directions. Environ. Sci. Technol. 53:2304-2315.
Smith, M.W., B.L. Carroll, and B.S Cheary. 2000. Mulch improves pecan tree growth during orchard establishment. HortScience 35:192-195.

Smith, D.R., C.H. Gilliam, J.H. Edwards, J.W. Olive, D.J. Eakes, and J.D. Williams. 1998. Recycled waste paper as a nonchemical alternative for weed control in container production. J. Environ. Hort. 16:69-75.

Sintim, H.Y. and M. Flury. 2017. Is biodegradable plastic mulch the solution to agriculture's plastic problem? Environ. Sci. Technol. 51:1068-1069.
Steed, S.T., A. Bechtloff, A. Koeser, and T. Yeager. 2018. Response of Japanese privet to plastic mulch applied over nonspaced containers. HortTechnology 28:58-65.

Stewart, C.J., S.C. Marble, B.J. Pearson, and P.C. Wilson. 2017. Impact of container nursery production practices on weed growth and herbicide performance. HortScience 52:1593-1600.

Wilson, C., T. Whitwell, and M.B. Riley. 1996. Detection and dissipation of isoxaben and trifluralin in containerized plant nursery runoff water. Weed Sci. 44:683-688 